\title{
The financing scheme in Mexico for university entrepreneurship
}

\section{El esquema de financiamiento en México para el emprendimiento Universitario}

\author{
RAMÍREZ-BARAJAS, Alejandro†*, CARMONA-GARCÍA, Nélida and ALMANZA-SERRANO, Ma. \\ Leticia
}

Universidad Tecnológica del Suroeste. Ingeniería en Negocios y Gestión Empresarial

ID $1^{\text {st }}$ Author: Alejandro, Ramírez-Barajas / ORC ID: 0000-0002-8426-3267, Researcher ID Thomson: S-8634-2018, CVU CONACYT ID: 228229

ID $1^{\text {st }}$ Coauthor: Nélida, Carmona-García / ORC ID: 0000-0003-0850-3668, Researcher ID Thomson: S-8608-2018, CVU CONACYT ID: 229857

ID $2^{\text {nd }}$ Coauthor: Ma. Leticia, Almanza-Serrano / ORC ID: 0000-0002-1481-5716, Researcher ID Thomson: S-8647-2018, CVU CONACYT ID: 230006

DOI: $10.35429 / J I E C .2019 .5 .3 .20 .26$

Received June 07, 2019; Accepted November 15, 2019

\begin{abstract}
The objective of this work is to identify the schemes, sources and financing instruments available for university entrepreneurship in Mexico from the change of federal government on December 1, 2018. The methodology applied for the development of this work consists of a review of the National Development Plan with the objective of identifying the plans, strategies and lines of action embodied in the document related to financing for university entrepreneurship. Subsequently, a review of the organizational structure of the current federal government was carried out to identify the entities and agencies whose functions are oriented to promote the economic development of the country through the granting of financing schemes for entrepreneurship and the form and requirements that must be met to access such schemes. The results obtained contribute to the strengthening of the applicable strategies of higher education institutions in terms of the entrepreneurial training of their students and, consequently, to the strengthening of the business ecosystem and economic development through the creation of employment-generating companies by the most trained agents.
\end{abstract}

Entrepreneurship, Financing, University

\section{Resumen}

El objetivo de este trabajo es identificar los esquemas, fuentes e instrumentos de financiamiento disponibles para el emprendimiento universitario en México a partir del cambio de gobierno federal el pasado 1 de diciembre del 2018. La metodología aplicada para el desarrollo de este trabajo consta en primera instancia de una revisión del Plan Nacional de Desarrollo con el objetivo de identificar los planes, estrategias y líneas de acción plasmados en el documento vinculadas con el financiamiento al emprendimiento universitario. Posteriormente se realizó una revisión de la estructura organizacional del actual gobierno federal para identificar las entidades y organismos cuyas funciones estén orientadas a promover el desarrollo económico del país mediante el otorgamiento de esquemas de financiamiento al emprendimiento y la forma y requisitos que se deben cumplir para acceder tales esquemas. Los resultados obtenidos contribuyen al fortalecimiento de las estrategias aplicables de las instituciones de educación superior en lo que a la formación emprendedora de sus educandos se refiere y en consecuencia, al fortalecimiento del ecosistema empresarial y desarrollo económico mediante la creación de empresas generadoras de empleo por parte de los agentes más capacitados para tal efecto.

Emprendimiento, Financiamiento, Universidad

Citation: RAMÍREZ-BARAJAS, Alejandro, CARMONA-GARCÍA, Nélida and ALMANZA-SERRANO, Ma. Leticia. The financing scheme in Mexico for university entrepreneurship. Journal- International Economy. 2019. 3-5:20-26

\footnotetext{
* Correspondence to Author (aramirez@utsoe.edu.mx)

$\dagger$ Researcher contributing first Author.
} 


\section{Introduction}

According to Sánchez (2016) when it comes to creating a company, if there is no firm financing scheme, it can become practically an impossible task. For this reason, it is necessary to know all the alternatives that exist for the financing of the enterprises that will result in the creation of companies and new businesses and to identify the most adequate for each case.

Financing a venture is mainly based on getting the money to pay for the investments needed for its proper execution. Generally, this money is not usually obtained for free, so it has a cost for the entrepreneur and the future company when it is returned. This financing cost depends mainly on the nature of the source of financing.

In the case of Mexico, it can be argued that there are four forms or sources of financing for a venture. The first of these is popularly known as the 3F's (Friends, Family and Fools), that is, family, friends and people close to the entrepreneur. This source of financing is, in many occasions, the first resource of the small entrepreneur who wants to execute a business project. In English, fools refer to "fools" or "madmen" but, if the idea is good, it does not have to mean a leap of faith for the borrower.

A second classification of financing sources can be defined as "formal" or "institutional". This classification refers to all entities that are formally and legally constituted with the objective of providing financing services of different kinds, including entrepreneurship. The main characteristic of this funding source is that the entrepreneur can know in advance the requirements, terms, amount and cost of the financing. In Mexico, this classification is based on the entities that make up the Mexican Financial System.

The third classification can be called "third party risk". It refers to financing obtained from groups of investors or individuals interested in financing business ventures where the most common cost of financing is the participation of shares in the venture. The fourth and last classification refers to the subsidies provided by the State as a subsidy to encourage certain productive sectors, in this case, the generation of enterprises.
Without a doubt, and despite the abundant documentation that must be presented and the bureaucracy that accompanies the process to obtain it, the subsidy is the most attractive source of financing for the entrepreneur, since the cost of financing is very low or nil. Given the high recurrence of entrepreneurs to finance their projects through government grants, it is necessary to identify the agencies, programs and schemes within the government structure in Mexico that make possible the financing of entrepreneurial projects.

This article presents the information gathered from an exhaustive review of the agencies and organizations that make up the Federal Administration 2019-2024, as well as their programs and strategies for financing entrepreneurship, taking as a reference for comparison the administration 2013-2018. It also presents a comparative table of grant funding with funding classified as formal. Taking as indicators of comparison the interest rate, the amount that can be financed, the term and the requirements for obtaining it, with the objective of presenting relevant and useful information for decision making regarding financing for entrepreneurship in Mexico.

\section{The National Development Plan and the entrepreneurship financing strategy}

The National Development Plan of the Federal Administration 2013-2018 headed by Mr. Enrique Peña Nieto considered at the time that the task of development and growth corresponds to all actors, all sectors and all people in the country. That development was not the duty of a single actor, not even one as central as the State. In the plan, and in order to achieve development in Mexico, the following goals were established:
1. A Mexico in Peace,
2. An Inclusive Mexico,
3. A Mexico with Quality Education,
4. A Prosperous Mexico and
5. A Mexico with Global Responsibility.

Regarding the promotion of the creation and development of companies, the goal of "Un México Próspero" of the National Development Plan was to detonate the sustained growth of productivity in a climate of economic stability and through the generation of equal opportunities. 
Likewise, the aforementioned goal sought to provide favorable conditions for economic development through the promotion of regulations that would allow for healthy competition among companies and the development of a modern policy of economic promotion, in order to create a greater number of jobs, develop the country's strategic sectors and generate more competition and dynamism in the economy. The aim was to increase the productivity of the dynamic sectors of the Mexican economy in a regional and sector balanced manner. To that end, the domestic market would be strengthened, entrepreneurs would be encouraged, micro, small and mediumsize enterprises would be strengthened, and the social economy would be fostered through better access to financing.

In the diagnosis prior to the design of the goal of " Un México Próspero" of the National Development Plan 2013, it was mentioned that in terms of economic promotion, sectoral and regional policy, it was indisputable that the policy aimed at supporting micro, small and medium-sized productive and formal enterprises and, of course, entrepreneurs, should be a cornerstone of the government's agenda, in order to consolidate it as a strategic lever for national development and the generation of well-being for Mexicans.

The strategies that were designed to achieve the goal of "Un México Próspero", in terms of the development of the country's strategic sectors, are listed below:

- Reactivate an economic promotion policy focused on increasing the productivity of the dynamic and traditional sectors of the Mexican economy, in a regional and sector balanced manner.

- $\quad$ Promote higher levels of investment and competitiveness in the mining sector.

- Guide and make public spending more efficient in order to strengthen the domestic market.

- Promote entrepreneurs and strengthen micro, small and medium enterprises.

Promote the social economy.

For the strategy of promoting entrepreneurs and strengthening micro, small and medium enterprises, the following lines of action were proposed:
To support the successful insertion of micro, small and medium-sized enterprises into the value chains of the most dynamic strategic sectors, with the greatest potential for growth and job creation, in agreement with the governments of the country's states.

- $\quad$ To promote entrepreneurial activity by creating an appropriate educational, financing, legal protection, and competition environment.

- $\quad$ To design and implement a system of information, monitoring, evaluation and dissemination of the impact of entrepreneurs and micro, small and medium enterprises.

- To promote programs that develop intensive capabilities in information and communication technologies, as well as innovation to promote the creation of high value-added ecosystems for micro, small, and medium-sized enterprises.

- $\quad$ To improve technical advisory services to generate an entrepreneurial culture.

- To facilitate access to financing and capital for entrepreneurs and micro, small, and medium-sized enterprises.

To create entrepreneurial vocations from an early age to increase the critical mass of entrepreneurs.

- $\quad$ To support the entrepreneurial scaling of micro, small, and medium-size Mexican enterprises.

- To increase the participation of micro, small, and medium-size enterprises in productive chains, as well as their export capacity.

- $\quad$ To promote the projects of social, green and high-impact entrepreneurs.

- $\quad$ To promote the creation of jobs through the development of entrepreneurial projects.

- To encourage the creation and sustainability of small formal businesses.

The previous extract from the National Development Plan 2013-2018 serves to highlight the importance of the work of financing entrepreneurship as an economic development strategy for the country for the Federal Administration in charge. 
As far as the National Development Plan 2019-2024 and its entrepreneurship financing strategy is concerned, it should be noted that the document does not mention the words "entrepreneurship" or "financing" throughout its 60 pages and mentions the term "Economic Development" only twice. Nevertheless, the word "Social" appears on 83 occasions. This makes evident, without going into too much depth, the orientation that the public policies contained in the NDP 2019-2024 will have.

\section{The government agencies promoting the venture.}

\section{The National Institute of the Entrepreneur}

With the National Development Plan 2013-2018 as the guiding axis of the financial policy, and almost simultaneously, the Federal Administration took on the task of creating the government agencies and tools that would allow the materialization of the mentioned financing policy for entrepreneurship. Thus, on December 7, 2012, a few days before the beginning of his presidency, Enrique Peña Nieto announced the creation of the National Institute of Entrepreneurs (INADEM).

The presidential announcement would be made by signing the decree for the creation of said institute on January 11, 2013, published in the Official Gazette of the Federation on January 14,2013 . The published decree consisted of the reform of the Internal Regulations of the Ministry of Economy by which the internal structure of such secretariat was modified to include INADEM and define it as a decentralized administrative body of the Secretariat, which aims to implement, execute and coordinate the national policy of inclusive support to entrepreneurs and micro, small and medium enterprises, promoting their innovation, competitiveness and projection in national and international markets to increase their contribution to economic development and social welfare, as well as to contribute to the development of policies that promote business culture and productivity.

INADEM's objectives during the 20132018 administration were the following:

To democratize productivity;

To encourage the emergence of more particularly high-impact entrepreneurs;
- To have a solid and broad base of productive and consolidated MSMEs;

To promote businesses with the possibility of competing in international markets; and

- $\quad$ To increase the number of companies with the capacity to scale up and grow.

The strategic lines of action were as follows:

- Support the successful insertion of MSMEs in strategic sectors defined jointly by the Ministry of Economy, those with the greatest dynamism, the greatest potential for growth, employment generation and value-added participation in export chains.

- Detonate productive projects of micro, small and medium enterprises in accordance with the productive vocations and the greatest regional competitive advantages of the country, taking advantage of the regional development policy that will be promoted by the Ministry of Economy.

Strengthen the financing ecosystem by diversifying and facilitating access to credit, so that financing effectively reaches MSMEs and entrepreneurs.

- Inculcate a new national entrepreneurial and business culture, based on innovation, to move towards an economy in which knowledge, science and applied technology serve as generators of wealth and well-being for Mexicans.

In order to meet its objectives, INADEM issued calls for proposals during the 2013-2018 period aimed at MSMEs, large companies, state governments, public trusts, municipal governments, civil associations, integration companies, business clusters, entrepreneurs, business incubators and accelerators, educational institutions, research centers, nonbank financial institutions, finance professionals, investor clubs, universities, public or private trusts, technology transfer offices (TTOs), investment promotion companies (IPs) and national and international capital funds. 
The objective of the calls was to reactivate the country's economy by financing strategies that increase sectoral and regional competitiveness, strategically articulate business clusters, promote technological innovation and its incorporation into MSMEs, institutionally strengthen non-bank financial intermediaries, and promote the creation, monitoring and strengthening of traditional enterprises, along with the creation of business incubators and accelerators.

Already in the Federal Administration 2019-2024 and according to Pineda and Sanchez, (2018) on December 7, 2018 the disappearance of INADEM was announced in the voice of the Secretary of Economy Dr. Graciela Marquez. She argued that, during the current administration, support would be provided directly by the agency in charge.

It should be noted that the disappearance of INADEM was announced at the same time as the presentation of the "Jóvenes construyendo el futuro" program. A program that, according to the NDP 2019-2023, is intended to enable young people between the ages of 18 and 29 who are neither studying nor working to receive job training. The scope of the program is 2.3 million young people. The federal government will grant them a monthly scholarship of $\$ 3,600$ pesos to train for one year in companies, public institutions and social organizations, where they will receive training to develop skills that will allow them to successfully enter the workforce. The training will last a maximum of twelve months.

The relationship between scholarship holders and tutors will not be of an employment nature. Scholarship holders also receive, through the IMSS, a medical insurance that covers accidents, illnesses, maternity and work risks during the period of their stay in the program. Scholarship holders must not perform tasks such as personal assistants, private security, watchmen, political party promoters or domestic work. Companies of all sizes and sectors can participate as tutors; individuals such as: plumbers, electricians, artisans and professionals; public institutions such as secretariats, municipalities, local governments, legislative and judicial branches, autonomous or decentralized bodies and international agencies; civil society organizations; universities, unions, schools, hospitals and museums, among others.
How does this program replace the economic development and entrepreneurship support functions that INADEM developed during the 2013-2018 administration?

\section{The National Institute of Social Economy}

On May 23, 2012, the Social and Solidarity Economy Law was published in the Official Gazette of the Federation, which regulates the social sector of the economy in accordance with the seventh paragraph of Article 25 of the Political Constitution of the United Mexican States. This law gave rise to the National Institute of Social Economy (INAES) as a decentralized administrative body of the Ministry of Economy.

During the 2013-2018 administration, INAES had the objective of implementing public policies to promote the social sector, in order to strengthen and consolidate the sector as one of the pillars of the country's economic development through participation, training, research, dissemination and support for productive projects in the sector.

During the period in question, INAES considered that young people are a strategic group to energize and exploit the potential of community forms of organization and work, typical of the social economy. For INAES, at that time, young people required options for productive insertion that would provide them with a stable income and guarantee them conditions of social well-being.

For this reason, INAES developed the Escala Project, the objective of which was to help generate a link for young people to move towards productive inclusion. Through the Escala Project, INAES supported initiatives that generated sources of work and income for young people, while developing collaborative links.

For the 2014 fiscal year, INAES issued seven calls for proposals aimed at social groups made up of men and women between the ages of 17 and 29 who were studying at public secondary and higher education institutions, individuals who belonged to a population identified as vulnerable, and organizations in the social sector of the economy (OSSE) with the general objective of promoting the generation of viable productive pre-projects in the social sector of the economy. 
Their financing and subsequent insertion in value chains in order to increase the opportunities for their productive and labor inclusion. INAES operated with the model called ESCALA, a three-stage model which the first stage was a contest to choose the best productive pre-projects that would obtain at that time, a cash incentive of $\$ 10,000.00$ (Ten thousand pesos) or an honorable mention, and that would have preference to participate in the second stage of the Project.

The second stage was the opportunity to transform the preliminary project into a productive project. Participants could obtain financing of up to 250,000 pesos to crystallize the project into a social economy enterprise. In the third stage, the company would be monitored and linked to entrepreneurs who were interested in the product or service and to other sources of financing that would ensure its consolidation.

In the 2019-2024 administration, INAES remains a decentralized body of the newly created (or renamed) Secretariat of Welfare. It aims to implement public policies to promote and develop the social sector of the economy, in order to strengthen and consolidate the sector as one of the pillars of economic and social development of the country, through participation, training, research, dissemination and support for productive projects of the sector. Unlike the 2012-2018 administration, INAES in the current administration directs its support exclusively to the Social Sector of the Economy Organizations (OSSE's).

Leaving out of reach of its support the Social Groups integrated by men and women between 17 and 29 years of age who were studying in Public High School and Higher Education Institutions and the individuals who belonged to a population identified as vulnerable under the previous administration. For the 2019 fiscal year, INAES has issued 11 calls for access to cash support. All of them are exclusively addressed to Social Economy Sector Bodies contemplated in its Catalogue of Social Economy Sector Bodies, which are listed below:
1. Ejidos.
2. Communities.
3. Unions of Ejidos.
4. Unions of Communities.

5. Rural Associations of Collective Interest made up of two or more Ejidos, Communities, Unions of Ejidos or Communities, Rural Production Societies made up of Ejidatarios and/or Communal Farmers or Unions of Rural Production Societies made up of Ejidatarios and/or Communal Farmers

6. Rural Production Companies integrated by two or more ejidatarios and/or communal farmers.

7. Unions of Rural Production Companies made up of ejidatarios and/or communal farmers.

8. Commercial companies with the participation of organizations from the social sector of the economy indicated in this Catalogue, with at least $51 \%$ of the capital stock.

9. Workers' Savings Banks.

10. Cooperative societies of goods and/or services producers.

11. Cooperative societies of consumers of goods and/or services.

12. Cooperative societies of savings and loans.

13. Cooperative bodies (Unions, Federations of Cooperative Societies of producers of goods and/or services; of consumers of goods and/or services; of savings and loans).

14. Social Solidarity Societies.

15. Mutual Societies constituted by any group of individuals, whether guild or non-guild

16. Credit Unions made up of ejidatarios, and/or communal farmers or any other body in the social sector of the economy mentioned in this Catalogue.

17. Community Financial Companies made up of ejidatarios and/or comuneros or any other body from the social sector of the economy indicated in this Catalogue.

18. Non-regulated Multiple Purpose Financial Companies, made up of ejidatarios and/or comuneros or any other body from the social sector of the economy indicated in this Catalogue.

Three of the eleven calls issued have national coverage and are aimed at strengthening and consolidating cooperative savings and loan societies (SOCAP's) and community financial societies (SOFINCO's). 
Two more are directed, or OSSE's, located in the municipalities with the greatest marginalization, the greatest presence of the indigenous population, and the highest rates of violence in the states of Chiapas, Guerrero, Oaxaca, Puebla and Veracruz that develop the economic activities marked in the call.

One more, directed to OSSE's that have as economic activity the production of milk and the possibility of delivering it in cold located exclusively in the region of Los Altos de Jalisco. One more is aimed at providing cash support to OSSEs made up exclusively of women for the implementation, development, consolidation and growth of social economy projects for production and consumption based on collective work and located in any of the municipalities identified by INAES as having a high rate of gender violence, and which have any of the production lines contemplated in the INAES Catalogue of Economic Activities.

One more, with national coverage, aimed at the OSSE's that have projects in nature tourism operation. One more directed to OSSE's with activities of cultivation of seed pumpkin or chihua, grain corn and papaya in the State of Campeche; cherry coffee, banana and mango in the State of Chiapas; pineapple, grain corn and corn in the State of Quintana Roo and grain corn, seed pumpkin or chihua and grain sorghum in the State of Tabasco. One more with national coverage and directed to OSSE's with economic activities of service provision and consumption of the following list:

$\begin{array}{ll}- & \text { Wholesale trade } \\ - & \text { Retail } \\ - & \text { Information in the mass media } \\ - & \text { Other services except government } \\ \text { activities } \\ -\quad \text { Storage, courier and parcel services } \\ -\quad \text { Temporary accommodation services, } \\ \text { food and beverage preparation } \\ \text { Business support and waste management } \\ \text { and remediation services } \\ \text { Generation, transmission, distribution } \\ \text { and marketing of electricity, water and } \\ \text { natural gas supply by pipeline to the final } \\ \text { consumer } \\ \text { Cultural and sports entertainment and } \\ \text { other recreational services } \\ \text { Health and social services } \\ \text { Educational Services }\end{array}$
- Professional, scientific and technical services
Tourist, passenger and cargo transport and transport services.

\section{Conclusions}

Unlike the National Development Plan 20132018, which set out an inclusive and diversified national strategy to support entrepreneurship, promoting the generation of new companies and the development and consolidation of existing ones and the corresponding generation of jobs, the National Development Plan 2019-2024 seems to aim to support a low-impact venture for the national economy. It focuses almost entirely on the financing of productive projects that generate self-employment and are aimed exclusively at Organizations in the Social Sector of the Economy (OSSE's) which, by the way, are made up of individuals from populations that are socially classified as vulnerable. Thus, the productive enterprises, micro, medium, and large companies that are the object of financing in the NDP 2013-2018 were replaced by the OSSE's of the NDP 2019-2024. As a result of the analysis developed in this work, the following questions need to be answered: What sources of financing will be available for university enterprises? Should university students be integrated into OSSE's to have access to financing schemes during the 2018-2024 sixyear period? These questions must be answered as soon as possible if we do not want to fall into a stagnation of business development and generation of new businesses and the corresponding employment generation that this entails.

\section{References}

https://www.gob.mx/inaes/acciones-yprogramas/convocatoria-vigentes

https://www.inadem.gob.mx/

Sánchez, L. (2016) Financiación de empresas. Retrieved August 5, 2019 from https://www.emprendepyme.net/financiacionempresas

Pineda, A. y Sánchez, A. (7 de diciembre, 2018) El Inadem desaparece, pero continúan los apoyos a emprendedores. Expansión. Available at:https://expansion.mx/emprendedores/2018/12 /07/el-inadem-desaparece-pero-continuan-losapoyos-a-emprendedores

RAMÍREZ-BARAJAS, Alejandro, CARMONA-GARCÍA, Nélida and ALMANZA-SERRANO, Ma. Leticia. The financing scheme in Mexico for university entrepreneurship. Journal- International Economy. 2019 